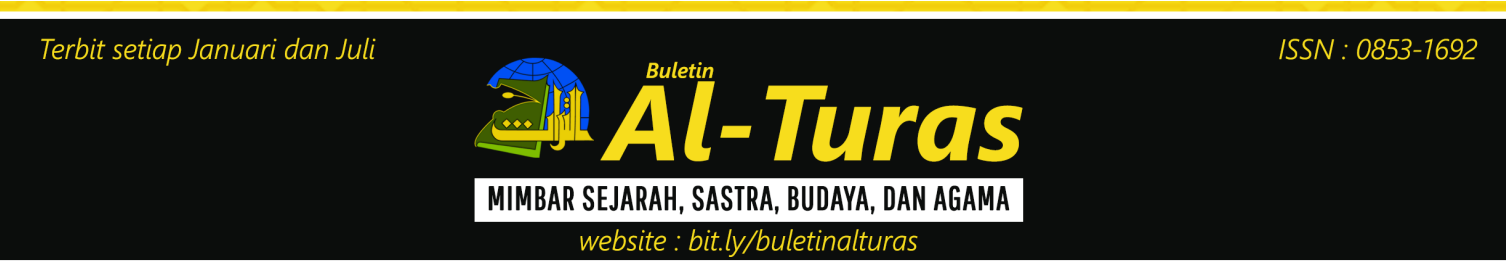

\title{
Perpustakaan Dalam Sejarah Islam: Riwayat Tradisi Pemeliharaan Khazanah Intelektual Islam
}

\author{
Didin Saepudin ${ }^{1}$
}

\section{Abstract}

Library in Islamic history plays in a very significant role. Its existence is very amazing as well as it becomes as an unseparated part of the Islamic civilization and Islamic knowledge development particularly at $8^{\text {Th }}-10^{\text {th }}$ century. Hypothetically, if library does not exist, knowledge will not develop fast as well. There are some functions of library. The first, it is a place where the science seekers look for the reference; the second, it becomes a center of a study for muslim scholar, the third, it stores and saves a very valuable manuscript work and books, the fourth, a place where muslims scholar conduct meeting or discussion, the fifth, library symbolizes a dignity of the Khalifa and the authorities.

Keywords: Bayt al-Hikmah, Baghdad, al-Rasyid, al-Ma'mun, Civilization.

\section{Abstrak}

Perpustakaan dalam sejarah Islam menempati posisi yang signifikan. Keberadaannya merupakan bagian integral dari perkembangan dan kemajuan ilmu pengetahuan dan peradaban Islam terutama pada abad 8-10 M. Kehadiran perpustakaan dalam sejarah Islam sangat mengagumkan baik dari segi pengelolaan, jumlah kitab, jumlah pemakai, dan apresiasi para khalifah waktu itu. Secara hipotetis dapat dikemukakan bahwa jika tidak ada perpustakaan di masa tersebut maka ilmu pengetahuan dan peradaban tidak akan mengalami kemajuannya. Atau setidak-tidaknya perkembangan ilmu akan berjalan sangat lambat dan tersendat-sendat. Fungsi Perpustakaan dalam sejarah Islam adalah pertama, tempat mencari bahan referensi bagi para penuntut ilmu di berbagai tingkat pendidikan; kedua, bahan kajian para intelektual Islam; ketiga, pusat penyimpanan bukubuku dan manuskrif berharga karya ilmuan, keempat, sebagai tempat pertemuan untuk kepentingan diskusi ilmiah dan debat intelektual, dan kelima, menjadi simbol kembanggaan khalifah dan penguasa setempat.

Kata Kunci: Bayt al-Hikmah, Baghdad, al-Rasyid, al-Ma'mun, Peradaban.

\footnotetext{
${ }^{1}$ Universitas Ibnu Khaldun (UIKA)
} 


\section{A. Pendahuluan}

Perpustakaan dalam sejarah Islam menempati posisi yang penting. Keberadaannya sangat sulit dipisahkan dari perkembangan dan kemajuan ilmu pengetahuan dan peradaban Islam terutama pada abad 8-10 M. Secara hipotetis dapat dikemukakan bahwa jika tidak ada perpustakaan di masa tersebut maka ilmu pengetahuan dan peradaban tidak akan mengalami kemajuannya. Atau setidak-tidaknya perkembangan ilmu akan berjalan sangat lambat dan tersendat-sendat jika tidak ada perpustakaan.

Karya-karya para ilmuwan Muslim dihimpun dalam perpustakaan yang tersebar di berbagai kota. Mehdi Nakosteen ${ }^{86}$ mencatat ada 36 perpustakaan di Baghdad sebelum diluluhlantakkan oleh pasukan Hulagu dari Mongol, di antaranya:

1) Perpustakaan Bayt al-Hikmah yangdidirikan oleh al-Ma'mun,

2) Perpustakaan Umar al-Waqidi yang diperkirakan memiliki 320 ekor unta beban

buku

3) Perpustakaan Dar al-Ilm,

4) Perpustakaan Nizamiyah,

5) Perpustakaan Madrasah Mustansiriyah,

6) Perpustakaan al-Baihaqy,

7) Perpustakaan Muhammad Ibn alHusain,

8) Perpustakaan Ibn Kamil.

Kekayaan khazanah intelektual Islam klasik itu berasal dari dua sumber;pertama, bersumber dari terjemahan-terjemahan manuskrip kuno dari berbagai peradaban praislam beserta komentar-komentar yang diberikan oleh ilmuwan muslim; kedua, bersumber dari karya-karya orisinal para ilmuwan Muslim itu sendiri dari berbagai jenis tradisi keilmuan.

Tokoh-tokoh sarjana
Muslim
mecara menakjubkan amat kreatif
Umumnya sarjana-sarjana Muslim
itu melahirkan ratusan karya ilmiah
berbagai jenis ilmu pengetahuan selama
hidupnya seakan-akan mereka hidup
hanya membaca,meneliti, dan menulis.
Ibn Hazm, misalnya, diriwayatkan
menulis 400 jilid buku yang totalnya
mencapai 80.000 halaman.

Semangat ilmiah dan tradisi menulis sarjana Muslim ini lalu dituangkan,di antaranya, ke dalam gedung-gedung perpustakaan. Perpustakaan itu banyak dibangun di masjid-masjid istana penguasa, rumah kaum ilmuwan Muslim dan bahkan di bawah tanah rumah-rumah orang kaya. Johannes Pedersen menuliskan hasil penelitian historisnya bahwa perkembangan seni produksi buku yang tak ada duanya dalam Islam disebabkan karena ketertarikan para hartawannya yang penuh semangat terhadap buku. Dunia ilmu telah menikmati kedudukan yang sedemikian tinggi sehingga wajarlah jika orang-orang yang mampu ikut mengambil bagian dan mengusahakan kemajuannya. Kita telah melihat betapa pentingnya para pembesar bagi para penulis dan banyak diantara mereka yang ikut mendirikan perpustakaan.

Menurut Seyyed Hossein Nasr, perpustakaan merupakan pusat pendidikan utama kaum Muslim. Pusat penting pertama yang khas menangani filsafat dan sains kealaman dan 
matematika adalah Bayt al-Hikmah, suatu perpustakaan yang di dalamnya juga terdapat observatorium; di bangun di Baghdad oleh Khalifah al-Ma'mun sekitar tahun $200 \mathrm{H} / 815 \mathrm{M}$. Ditunjang oleh perbendaharaan negara, Bayt alHikmah itu menjadi tempat berkumpul banyak saintis dan sarjana.

Di tempat itu pulalah berhimpun ahli terjemah yang cakap yang menerjemahkan hampir seluruh literatur ilmiah dan filosofis Yunani ke bahasa Arab dan merupakan landasan bagi penyerapan literatur tersebut di dalam Islam. Menurut Nasr, jumlah terjemahan dari bahasa Yunani, Suriah, Pahlavi, dan Sansekerta selama abad ke 9 dan 10 adalah sedemikian banyaknya sehingga sekarang pun manuskrip-manuskrip dari berbagai peradaban praislam tersebut lebih banyak terdapat dalam bahasa Arab di banding dalam bahasa Eropa modern mana pun.

Kecemerlangan perpustakaan Islam, menurut Pedersen, terjadi pada kekhalifahan Fathimiyah di Kairo. Pada tahun 1005, Khalifah al-Hakim membangun Dar al-'Ilm di Kairo. Dinasti Fathimiyah yang menyatakan diri sebagai keturunan putri Rasulullah, Fathimah, membangun Kairo yang sepenuhnya baru di sisi Kairo yang lama, dengan istana yang begitu megah dan sebuah masjid, al-Azhar, yang sejak saat itu merupakan pusat Dunia Islam. Mereka mendirikan perpustakaan di istana itu, dan juga di masjid-masjid lain.

Khalifah al-Hakim mendirikan sebuah akademi yang dilengkapi dengan perpustakaan di bawah tanah istana Fathimiyah. Buku-buku dari seluruh cabang ilmu yang ada pada zaman itu terkoleksi di perpustakaan Dar al-Ilm tersebut. Diriwayatkan bahwa bangunan perpustakaan itu dihiasi dengan karpet di lantai dan dindingnya; dan selain buku, disediakan juga kertas, pena, dan tinta untuk umum. Siapa saja boleh masuk dan lembaga itu didatangi oleh berbagai kelas dalam masyarakat yang ingin membaca, menulis, dan mendapat pegajaran. Peneliti, para asisten dan pesuruh dipekerjakan dengan gaji tetap, dan para ilmuwan pun diberi gaji berstandard tinggi untuk melakukan telaah di lembaga tersebut.

Menurut K Ajram, pada abad ke-13 perpustakaan Fathimiyah di Kairo memiliki koleksi sebanyak dua judul buku. Perpustakaan di Tripoli juga tak kalah banyak. Secara umum pada abad ke-13 itu telah tersedia sekitar lima juta judul buku: suatu jumlah yang amat banyak untuk ukuran waktu. Hal itu bisa dibandingkan, misalnya, dengan jumlah buku yag tersedia di perpustakaan terbesar Amerika sekarang ini, yaitu New York Public Library tercatat sekitar tujuh juta judul buku.

Ketika Dinasti Fathimiyah mengangkat citra Mesir sebagai pusat peradaban Islam terkemuka di dunia, ada seorang penguasa keturunan Umayyah di Kordoba, al-Hakam, yang pada akhir abad ke-10 mendirikan perpustakaan besar. Dia mengumpulkan para ilmuwan dan pemimpin masjid, dan masjid besar di Kordoba dibuat menjadi pusat telaah. Perpustakaan yang berada di dalam istana Kordoba itu diurus oleh petugas perpustakaan, juga mempekerjakan para penyalin dan penjilid buku. AlHakam mempunyai agen-agen di setiap provinsi yang menyediakan buku untuknya dengan cara membeli dan menyalin. Perpustakaan itu terbuka untuk masyarakat umum.

Sayangnya, ketika khalifah al-Mansur terpengaruh oleh para ahli 
agama ortodoks yang kurang atau tidak berkenan kepada buku-buku ilmu seperti karya-karya filsafat, astronomi dan ilmu-ilmu umum lainnya yang dianggap sekular, banyak buku ilmu-ilmu tersebut yang dibakar. Pembakaran atau pemusnahan buku-buku itu merupakan awal malapetaka etos keilmuan Islam yang sampai hari ini kita rasakan akibatnya, yaitu sedemikian rendahnya semangat keilmuan di negeri-negeri kaum Muslim.

\section{B. Pembahasan}

\section{Kategori Perpustakaan}

Fungsi Perpustakaan dalam sejarah Islam adalah pertama, tempat mencari bahan referensi bagi para penuntut ilmu di berbagai tingkat pendidikan; kedua, bahan kajian para intelektual Islam; ketiga, pusat penyimpanan buku-buku dan manuskrif berharga karya ilmuan, keempat, sebagai tempat pertemuan untuk kepentingan diskusi ilmiah dan debat intelektual, dan kelima, menjadi simbol kembanggaan khalifah dan penguasa setempat.

Menurut Mehdi Nakosteen, terdapat tiga jenis perpustakaan pada abad-abad permulaan Islam: Umum, Semi Umum, dan Pribadi. Yang digolongkan pada perpustakaan umum adalah Bayt al-Hikmah, Perpustakaan Haidari di Najaf, Perpustakaan Ibnu Sawwar di Basrah, Perpustakaan Darul Ilmi di Bagdad, Darul Ilmi di Bagdad milik al-Syarif al-Radi, Perpustakaan Masjid dari al-Zaid, Darul Ilmi (Darul Hikmah), Perpustakaan Kairo dan sejumlah perpustakaan perpustakaan sekolah terkenal.

Perpustakaan-perpustakaan semi pribadi yang berhasil didaftar adalah
al-Nasirudinullah, al-Mu'tashim billah dan perpustakaan Khalifah-khalifah Fatimiyah. Sedangkan perpustakaan pribadi yang berhasil didata adalah perpustakaan yang dimiliki oleh al-Fath ibn Khaqan, Hunaya ibn Ishaq, Ibnul Khasysyab, al-Muwaffaq ibnu Matram, Jamaluddin al-Quifri, Ufra'im ibnul Zaffan, Quaduddin al-Isfahani.

Usaha yang dilakukan di perpustakaan pribadi menyertai lahirnya lingkaran-lingkaran studi dan munculnya penjual-penjual buku dalam kehidupan intelektual Islam. Orang-orang Islam dari semua kalangan sangat menghargai buku, sebab al-Quran menghargai dunia keilmuan di atas semuanya. Penguasaan atas ilmu pengetahuan dan sebuah sistem budaya merangsang individu untuk mengusahakan salinan-salinan manuskrip penting yang mereka miliki sendiri terutama al-Quran; termasuk juga karya-karya sastra, filsafat dan sains. Harga manuskrip-manuskrip sangat mahal; bahkan manuskripmanuskrip yang dijilid dengan bagus jauh lebih mahal lagi. Jadi pada mulanya perpustakaan cenderung didirikan di rumah-rumah orang kaya, kalangan bangsawan dan di istana-istana para penguasa. Karena ajaran-ajaran alQuran mengharuskan individu-individu untuk mengajarkan ilmu pengetahuan dan menyediakan kekayaanyang dimilikinya bagi orang-orang lain yang kurang beruntung, maka para hartawan membiayai pembangunan perpustakaan dan seringkali membukanya untuk para ilmuwan dan kadang-kadang untuk umum.

Khalifah-khalifah dan perdana mentri (Wazir) Muslim mendorong ilmu pengetahuan di seluruh kota-kota penting Islam dan menyediakan perpustakaanperpustakaan yang ada bagi siapa 
saja yang peduli menggunakannya. Bahkan monarki-monarki tersebut membuka perpustakaan perpustakaan pribadi mereka untuk umum terutama Samaniyah di Bukhara dan Hamdaniyah di Syria dan Buyiyah di Shiraz. Ibnu Sina melaporkan digunakannya secara bebas perpustakaan kerajaan Sultan Nuh ibn Mansur.

Ibnu Abbad tidak saja mengijinkan penggunaan secara bebas perpustakaannyayangterkenaltetapijuga memberi 1000 dirham dan seperangkat pakaian kepada setiap cendikiawan untuk menggiatkan pengetahuan dan kecendikiaan. Perpustakaan milik penyair Ibnu Hamdan telah dibuka untuk semua mahasiswa; demikian juga pada perpustakaan Adud Daulah di Basrah telah dibuka untuk para cendikiawan bahkan bagi orang-orang yang membaca dan menulis di sana akan menerima beasiswa. Perpustakaan lain telah didirikan untuk para mahasiswa oleh pemilik tanah yang kaya di Isfahan. Qadi di Nishapur, Ibnu Hibban, mewariskan rumahnya di kota bersama-sama dengan sebuah perpustakaan dan tempat tinggal untuk mahasiswa-mahasiswa asing dan menyediakan upah untuk perawatannya.

Ahli Geografi Yaqut al-Hamawi menyatakan bahwa selama tiga tahun ia tinggal di Merv bermacammacam perpustakaan amat banyak meminjamkan buku-buku. Ia sendiri menyatakan "rumahku tidak pernah kosong dari lebih 200 volume bukubuku yang saya pinjam dan saya tidak pernah memberi uang sewa walaupun buku-buku tersebut bernilai 200 dinar".

Perpustakaan yang terkenal dari Khalifah al-Hakim di Kairo terletak di sekolah tinggi dan didirikan pada tahun 1004 M. Perpustakaan ini memiliki koleksi buku-buku yang banyak yakni
1.600.000 volume dan dibuka untuk umum sebagai pusat ilmu pengetahuan dan penelitian (riset).

Dalam akademi al-Hakim di Fatimiyah, Kairo, mahasiswamahasiswa dari golongan tak mampu disuplai dengan tinta, pena dan kertas. Al-Hakim menyediakan anggaran lebih dari 200 dinar setiap tahun untuk perawatan perpustakaan tersebut.

Khalifah al-Hakim II mendirikan sebuah perpustakaan besar di Cordova pada dekade akhir abad kesepuluh yang diperkaya dengan buku-buku terbaik. Buku-buku tersebut dibeli Khalifah dari penyalur buku di semua pasarpasar buku dunia Muslim. Perpustakaan terbuka untuk semua orang yang ingin menggunakannya; para mahasiswa kurang mampu dan para cendikiawan yang menuntut ilmu pengetahuan menerima bantuan finansial dari khalifah. Khalifah terpelajar ini sendiri adalah cendikiawan dan mahasiswa terbaik di perpustakaan.

Sementara itu menurut Raghib alSirjani, perpustakaan Islam terdiri lima macam yaitu perpustakaan akademi, perpustkaan khusus, perpustakaan umum, perpustakaan sekolah dan perpustakaan masjid. $^{2}$

1. Perpustakaan Akademi merupakan perpustakaan paling terkenal dalam peradaban Islam. Diantara yang paling terkenal adalah perpustakaan Baghdad (Baitul Hikmah). Hal ini akan kita bicarakan dalam pembahasan mendatang.

2. Perpustakaan Khusus. Perpustakaan jenis ini telah menyebar di segala penjuru negeri Islam den-

2 Raghib al-Sirjani, Sumbangan Peradaban Islam pada Dunia, Jakarta: Pustaka al-Kautsar, 2009, hlm. 237. 
gan bentuk yang luas dan baik. Di antara perpustakaan itu adalah Perpustakaan Khalifah al-Muntashir ${ }^{3}$, Perpustakaan al-Fatah bin Khaqan ${ }^{4}$, Perpustakaan Ibnu al-Amid, menteri Ali Baweh yang terkenal. Ibnu Maskawiyah salah seorang sejarawan terkenal menyatakan bahwa dia menjadi pustakawan di perpustakaan Ibnu Amid. Ibnu Amid mengisi perpustakaannya dengan buku-buku yang sangat banyak, yang diperkirakan sebagian bukunya itu ada yang dicuri. Dari realitas yang terjadi ini, kita melihat bahwa perpustakaan-perpustakaan itu sangat banyak dan sangat besar kontribusinya. Sebagaimana diceritakan oleh Ibn Maskawiyah, "Aku sibuk membolak-balik daftar (deretan) buku milik Menteri Ibnu al-Amid, tidak ada satupun yang lebih hebat dari perpustakaan ini, bukunya begitu banyak. Di dalam perpustakaan tersebut tersedia segala macam bidang ilmu seperti ilmu hukum dan adab, yang jumlahnya hampir mencapai seratus wiqr. Juga perpustakaan al-Qadhi Abu Matraf, yang terhimpun di dalamnya kitab-kitab yang belum pernah dikumpulkan oleh siapa pun orang sezamannya di Andalusia. ${ }^{5}$

3. Perpustakaan Umum. Di antara contoh perpustakaan ini adalah perpustakaan Cordova yang didirikan Khalifah Al-Umawi al-Hakam al-Muntasir tahun 350 H/961 M di Cordova. Dalam perpustakaan tersebut dipekerjakan pegawai khusus untuk memelihara buku-

${ }^{3}$ Ibn Katsir, Al-Bidayah wa al-Nihayah,(Beirut: Dar el-Fikr, 1933), hlm. 186.

${ }^{4}$ Adz-Dzahabi, Tarikh Islam, hlm. 375.

${ }^{5}$ Adz-Dzahabi, Tarikh Islam, hlm. Hlm. 61. buku, mengumpulkan naskah-naskah, dan melayani para pengguna yang mencari rujukan. Bangsa Eropa juga telah megutus pelajarnya untuk menimba ilmu dan mendalaminya, berkompetisi meraih supremasi keilmuan. Juga terdapat perpustakaan Bani Imar di Tripoli, Syam.

4. Perpustakaan Sekolah. Peradaban Islam sangat memprioritaskan perhatiannya untuk mendirikan sekolah-sekolah supaya semua orang dapat menuntut ilmu. Di setiap sekolah harus didirikan perpustakaan sebagai sesuatu yang wajib demi menunjang kelancaran proses belajar mengajarnya. Sekolah-sekolah dalam dunia Islam menyebar dengan luas hampir meliputi segala penjuru negeri, dari Irak, Suriah, Mesir, dan sebagainya. Semua sekolah Islam tersebut dilengkapi dengan perpustakaan. Nuruddin Mahmud membangun sekolah di Damaskus dan mendirikan perpustakaan. Begitu pula apa yang dilakukan Shalahuddin. Sementara Qadhi al-Fadhil, Menteri Shalahudin, membangun sekolah di Kairo yang diberi nama al-Fadhilah. Ia juga memberikan hadiah kepada sekolah tersebut sebanyak 200.000 jilid buku yang diambil dari koleksi buku di al-Abidiyina. Yakud al-Himawi menyebutkan beberapa sekolah di Marwa, yang pada masanya merupakan perpustakaan yang sangat megah, pintu-pintunya terbuka untuk semua kalangan ${ }^{6}$.

5. Perpustakaan Masjid dan Universitas. Perpustakaan jenis ini ditetapkan sebagai perpustakaan pertama

\footnotetext{
${ }^{6}$ Raihi Mustafa Ulyan, Al-Maktabah fi al-Had-
} harah al-Arabiyah al-Islamiyah, hlm. 134. 
dalam Islam. Perpustakaan tumbuh dalam sejarah Islam seiring tumbuh dan didirikannya masjid. Di antara perpustakaan ini adalah: Maktabah universitas al-Azhar dan Maktabah universitas al-Kabir di Qarawain ${ }^{7}$.

\section{Perpustakaan Penting Islam}

\section{a. Dari Baghdad sampai Nisha- pur}

Sebelum diluluhlantahkan oleh bangsa Mongol, Bagdad dibanggakan oleh 36 buah perpustakaan, di antaranya a) peprpustakaan al-Waqidi yang diduga memiliki 120 ekor unta beban buku-buku, b) Baitul Hikmah ${ }^{5}$ c) Darul Ilmi d) Perpustakaan Nizhamiyah e) Perpustakaan Mustansiriah f) Perpustakaanal-Baiqani g) Perpustakaan Muhammad Ibnu Husain dari Haditsa yang berisi koleksi manuskripmanuskrip langka; disimpan di tempat terkunci h) Perpustakaan Ibnu Kamil dengan 10.000 buku$^{6}$. Di samping itu lebih dari 100 penyalur buku di Bagdad benar-benar menerbitkan manuskrip dalam bentuk salinan tulisan tangan.

\section{b. Di Persia}

Perpustakaan Ibnu Hamid di Rayy pernah dijarah oleh beberapa orang Jamaah yang menyimpang. Menurut Philip K.Hitti, perpustakaan di Rayy berisi manuskrip yang bila diangkut oleh unta maka akan dibutuhkan sebanyak 400 ekor unta ${ }^{7}$.Perpustakaan penyair Ibnu Hamdan di Mosul telah memberi buku-buku semua cabang ilmu pengetahuan kepada sekolah tinggi yang ia dirikan di kota itu.

\footnotetext{
${ }^{7}$ Said Ahmad Hasan, Anwa al-Maktabat fi al-Alamina wa al-Islam, hlm. 18-78.
}

Perpustakaan Adud Dawlah memiliki dua cabang. Di samping satu perpustakaan miliknya di Basrah, ia membangun sebuah perpustakaan yang luas di pekarangan istananya di Shiraz. Dalam sejarah, Adud al-Dawlah adalah amir Buwayh ${ }^{8}$ yang paling besar. Philip K. Hitti menyebutnya "the most illustrious ruler in his time" (penguasa paling termahsyur di masanya $)^{9}$. Pada masanya Bagdad menjadi kota ilmu dan peradaban. Banyak lahir para cendikiawan yang kemudian memiliki nama dan pengaruh yang besar ${ }^{10}$. Ia adalah orang yang mencintai belajar dan banyak memberikan dana beasiswa kepada para teolog, ahli hukum, ahli fisika, matematika, dan mesin. Kepada para filosof, ia menyerahkan satu ruang yang luas di istanannya. Ruang itu berada disamping ruang kerjanya dengan maksud agar mudah mendiskusikan masalah-masalah dengan para filosof itu $^{11}$.Ia juga membangun rumah sakit yang terkenal yang diberi nama dengan namanya yakni Bimaristan al-Adudi.

Pada abad ke-13, pada saat baru saja terjadi invasi Mongol, paling tidak ada 10 perpustakaan lain, delapan di antaranya terletak di berbagai sekolah tinggi dan dua di masjid Perpustakaan lain Persia adalah Isfahan, Shiraz, Merv, Mosul, Basrah, Ghazna dan Nishapur.

Di Bukhara, raja Nuh ibn Mansur membangun sebuah perpustakaan besar yang meliputi berbagai macam ilmu. Ibn Sina pernah menyebutkan bahwa beberapa macam buku dalam bidang filsafat terdapat dalam perpustakaan itu. Sahib bin Abbad menolak ketika hendak diangkat menteri oleh Nuh bin Mansur. Alasannya sarjana terkemuka ini harus menyiapkan 400 ekor unta untuk mengangkut buku-bukunya. Perpustakaan Sahib bin Abbad begitu 
besar sehingga katalognya saja terdiri dari 10 jilid. Dia seorang Filolog yang menaruh perhatian pada masalahmasalah filsafat dan ilmu ${ }^{12}$.

\section{c. Di Afrika Utara}

Di Kairo terdapat sejumlah peprpustakaan terkenal antara lain: Perpustakaan Baitul Hikmah yang didirikanoleh al-Aziz (975-976), khalifah Fatimiyah. Perpustakaan ini berisi tidak kurang dari 100.000 volume, sebanyak 600.000 jilid buku termasuk 2400 al-Quran berhiaskan emas dan perak disimpan di ruang terpisah.

Perpustakaan al-Fadhil telah dirampas oleh Abu al-Faraj pada tahun 1068; buku-buku berharga diangkut oleh 25 ekor unta-beban.Buku-buku tersebut semuanya telah dibakar oleh tentaraTurki beberapa tahun kemudian. Untuk merestorasi perpustakaan tersebut diperlukan waktu satu abad lebih. Pada tahun 1171, ketika Sultan Saladin memasuki Kairo ia telah mendirikan perpustakaan dengan 120.000 volume di dalam istana dan menyerahkannya kepada seorang penanggung jawab terpelajar bernama al-Qadi al-Fadhil.

Perpustakaan pangeran Ben Fatiq, seorang cendikiawan dan penulis terpelajar adalah di antara perpustakaanperpustakaan pribadi Yahudi dan Muslim, di Kairo. Perpustakaan alMa'arif berisi ribuan buku dari setiap cabang ilmu pengetahuan. Di sampul belakang tiap-tiap volume terdapat komentar yang menyatakan kualitas buku tersebut yang ditulis oleh alMa'arif sendiri.

\section{d. Perpustakaan di Spanyol dan Sisilia}

Di wilayah ini terdapat lebih dari 70 perpustakaan Muslim. Perpustakaan Khalifah al-Hakim (w. 976 M) di Cordova berisi sekitar 600.000 volume. Buku-buku yang ada adalah bukubuku pilihan hasil seleksi para ahli dan para penyalur buku. Perpustakaan ini dipimpin oleh sebuah staf yang cukup besar terdiri dari para pustakawan, penyalin dan penjilid. Perpustakaan Abu Mutrif, seorang hakim Cordova, kebanyakan berisi buku-buku langka. Perpustakaan ini terjual dalam lelang sebesar 40.000 dinar setelah ia wafat tahun $1011 \mathrm{M}$.

\section{Perpustakaan Yahudi yang ber- hubungan dengan Islam}

Di antara perpustakaanperpustakaan Yahudi, ada beberapa yang sigifikan bagi kebudayaan Islam. Yaqub ben Killis, atas jasa Khalifah di Kairo tahun 979, didorong oleh cendikiawan Muslim, mempekerjakan banyak penyalin buku untuk membuat salinan buku-buku tentang undangundang kedokteran dan pengetahuan ilmiah. Setiap bulan perpustakaan ini menghabiskan 1000 dinar emas untuk para cendikiawan dan gaji para penyalin serta penjilid ${ }^{13}$.

Ahli kedokteran abad kesebelas, Ephraim, memiliki koleksi besar buku-buku ilmu kedokteran. Sepuluh ribu volume dan koleksinya akhirnya diangkut ke perpustakaan Afdad, putra Amir al-Juyusy, tetapi sebanyak 20.000 volume masih tersisa dalam koleksi miliknya.

Ahli kedokteran Abraham ben Hillel (Abul Izz) memiliki sebuah perpustakaan yang sangat luas, berisi karya-karya Maimonides, Galen, 
Hippocrates dan Averroes. Perpustakaan tersebut terjual dalam suatu lelang.

Ahli kedokteran
lainnya, Leo Mosconi dari
(permulaan aborea
pad ke 14) memiliki sebuah perpustakaan buku-buku ilmu kedokteran dan buku-buku lainnya. Perpustakaan ini juga terjual dalam suatu lelang. Di dalamnya terdapat karya Avicenna, Averroes, demikian juga karya-karya para penulis Yunani dan Hebrew dengan risalah-isalah tentang astronomi, anatomi, meteorologi, pengobatan, fisika, musik, logika, etika, dan gramatika.

Perpustakaan milik ahli kedokteran David d'Estella di Prancis berisi karya-karya Aristoteles dan Maimonides.

\section{Lebih Jauh tentang Bayt al-Hik- mah}

Perpustakaan paling terkemuka di Baghdad tidak lain adalah Bayt al-Hikmah. Perpustakaan tersebut mencerminkan perbendaharaan ilmiah yang paling bernilai dalam pemikiran Islam. Karena begitu lengkapnya, dapat dibandingkan bahwa perpustakaan ini setaraf kedudukannya dengan universitas ilmiah kelas dunia di masa modern. Keberadaannya menjadi pusat tujuan para pencari ilmu dari berbagai negara, timur maupun barat. Eksistensinya telah memberi pencerahan kepada dunia hingga kurang lebih lima abad sampai hancur lebur di tangan orang-orang Tartar pada abad ke $13 \mathrm{M}$.

Pendiri perpustakaan ini adalah Khalifah Abbasiyah kedua, Abu Ja'far al-Manshur ${ }^{8}$ di ibukota kekhalifahan,

\footnotetext{
${ }^{8} \mathrm{Abu}$ Jafar al-Mansur adalah Khalifah kedua Dinasti Abbasiyah menggantikan Abu al-Abbas al-Saffah. Dalam sejarah banyak disebut bahwa dialah Pembina sebenarnya Dinasti Abbasiyah.
}

Baghdad. Ia mendirikan perpustakaan ini untuk menyimpan buku-buku dan kitabkitab bermutu baik yang bersumber dari tulisan-tulisan bangsa Arab maupun terjemahan dari bahasa nonarab.

\section{Ketika Khalifah Harun al-} Rasyid memerintah dari tahun 170 sampai 193 H, ia memerintahkan supaya mengeluarkan buku-buku dan naskahnaskah yang ada untuk diterjemahkan. Ia membuatkan bangunan khusus yang sangat luas dan megah, kemudian semua kitab-kitab simpanan itu dipindahkan ke tempat tersebut dan diberinya nama Bayt al-Hikmah. Setelah itu, Bayt al-Hikmah berkembang pesat dan menjadi pusat akademi imliah paling terkenal dalam sejarah. Perkembangan Bayt al-Hikmah semakin bertambah besar di masa pemerintahan al-Ma'mun. Ia banyak mengundang penerjemah-penerjemah besar, para penyalin, para ulama dan para penulis. Bahkan, ia mengutus misi ilmiah sampai ke negara Romawi, yang saat itu sedang berjaya dengan kekaisaran dan kedigdayaannya ${ }^{9}$.

Selanjutnya, Bayt al-Hikmah berkembangmenjadi perpustakaan khusus dan pusat penerjemahan, disusul kemudian menjadi pusat penelitian dan penulisan; kemudian berkembang lagi menjadi rumah ilmuatau semacam akademi yang mengeluarkan ijazah. Terakhir menjadi pusat kajian astronomi.

Bayt al-Hikmah terbagi menjadi beberapa bagian, dengan rincian sebagai berikut:

\section{1) Perpustakaan}

Bagian perpustakaan ini merupakan divisi untuk meneliti kitab-kitab karangan siapapun agar tidak terjadi atau terindikasi adanya penyimpangan. Kitab-kitab tersebut disusun di atas ${ }^{9}$ Al-Shafadi, al-Wafi al-Wafayat, hlm. 336. 
rak-rak dan bisa diambil oleh siapa saja yang membutuhkannya. Karena itu, harus ada bagian naskah dan penjilidan yang mengikat ruang tempatnya untuk mentranskrip kitab-kitab lalu menjilidnya dan menghindari sesuatu yang mungkin dapat merusak. Di antara cara menambah buku Bayt al-Hikmah adalah dengan membeli buku, dimana dalam pembelian buku ini Khalifah al-Ma'mun telah mengirim utusan ke Konstantinopel untuk menghadirkan bermacam buku. Terkadang, dia pergi sendiri membeli buku dan mengirimkannya ke Bayt al- Hikmah. Ada juga dengan cara lain, dimana khalifah mengutus para utusan Islam ke negeri asing, kemudian mengobservasi kitab-kitab yang ada pada mereka. Atau meminta pembayaran jizyah (pajak) dengan buku. Dengan caracara pengadaan bahan pustaka seperti itu maka terpenuhilah kebutuhan akan bahan pustaka yang memenuhi ruang-ruang perpustakaan Bayt al-Hikmah.

Pada satu misi utusan, Khalifah al-Ma'mun pernah menulis surat kepadaraja Romawi untuk meminta izin mendayagunakan apa yang ada disana berupa ilmu-ilmu kuno yang tersimpan dan menjadi warisanbangsa Yunani. Waktu itu, bangsa Romawi melarang mengkajinya. Namun sesudah itu Raja Romawi menjawab danmenyambut baik seruan itu. Al-Ma'mun menyiapkan duta keilmuan, menambah beberapa rombongan para penerjemah, mengangkat pemimpin sebagai mushrif (penanggung jawab) di perpustakaan Bayt al-Hikmah. Lalu dimulailah perjalanan utusan ke berbagai daerah. ${ }^{10}$.

\section{2) Pusat Penerjemahan}

\footnotetext{
${ }^{10}$ Ibn Nadim, Al-Fihrist, Al-Fihrist, (Kairo: Maktabah al-Nahdah al-Mishriyah, 1935), hlm. 304.
}

Al-Ma'mun memfokuskan revolusi besar-besaran dan menakjubkan terkait kitab-kitab peninggalan zaman kuno. Di masanya terbentuklah badan penerjemah dan pensyarah yang bertugas mengalihbahasakan bahasa kitab itu ke bahasa Arab. Adanya tim penerjemah ini juga dimaksudkan agar naskah kuno itu tidak sampai punah atau hilang. Al-Ma'mun menentukan penanggung jawab penerjemahan dan memberikan gaji kepada mereka dengan gaji yang besar. Setiap bulan mereka digaji 500 dinar ${ }^{11}$ atau setara dengan dua kilogram emas.

Bagian ini menerjemahkan buku dari berbagai bahasa yang berbeda-beda ke dalam bahasa Arab; terkadang juga dari bahasa Arab ke bahasa lain. Di antara penerjemah itu adalah Yohana bin Masuwiyah, Jibril bin Bakhtisyu ${ }^{12}$, Hunain bin Ishak yang diutus untuk mendalami bahasa Yunani. Kitab-kitab bahasa asing disimpan dalam perpustakaan dan diterjemahkan. Ada juga sebagian penerjemah mengerjakan tugasnya di luar perpustakaan danpihak perpustakaan mengambil hasil terjemahan tersebut. Ibnu Nadim menyebutkan dalam bukunya al-Fihrist, sepuluh nama yang tergabung sebagai tim penerjemah dari bahasa India, Yunani, Persia, Suryaniyah, Nibthiniyah. Mereka tak hanya sebatas menerjemahkan kitab ke dalam bahasa Arab, tetapi juga menerjemahkan bahasa-bahasa yang dipakaikaum Muslimin nonarab. Dengan demikian, penerjemah itu bisa berfungsi ganda, sebagai penerjemah kitab-kitab berbahasa nonarab, sekaligus penerjemah bahasa-bahasa Muslim yang bukan atau tidak bisa berbahasa Arab. Di antara mereka ada yang

\footnotetext{
${ }^{11}$ Ibn Abi Ashibah, Uyun a-Anba, hlm. 133.

${ }^{12}$ Jibril bin Bakhtisyu adalah dokter yang jenis, yang dipanggil ke istana untuk menjadi dokter Khalifah Harun al-Rasyid dan al-Ma'mun.
} 
menerjemahkan bahasa Arab ke bahasa nonarab, dan yang lain menerjemahkan dari bahasa nonarab ke bahasa Arab. Yohana bin Masuwiyah yang menerjemahkan kitab ke bahasa Suryaniyah, kemudian memberikan tugas kepada penerjemah lainnya untuk menerjemahkannya ke bahasa Arab. Dengan begitu, keaslian bahasa dapat tetap terjaga dan terpelihara dengan baik. ${ }^{13}$.

Banyak isyarat yang menunjukkan bahwa kebanyakan kitabhasil terjemahan adalah berasal dari bahasa Nibtiyah, Qibtiyah, Suryaniyah, Persia, India, dan Yunani. Para ilmuan Islam telah mempersembahkan peran yang besar bagi banyak orang dengan memindahkan dan menerjemahkan buku-buku kuno yang hampir hancur dan musnah. Andai bukan lantaran jerih payah mereka niscaya orang-orang di masa sekarang tidak akan mengetahui warisan intelektual Yunani dan India. Mereka akan tertutup untuk melacaknya di banyak negara yang menyimpannya. Apalagi sebagian karya itu ada yang telah dibakar karena khawatir pengaruh dari pemikirnya, seperti yang terjadi terhadap buku Archimedes, salah seorang ilmuan terkenal. Kerajaan Romawi membakar bukunya sebanyak lima belas kargo (beban muatan $)^{14}$, dengan alasan mencegah pemikirannya yang salah itu tersebar.

Peran para ilmuwan tidak terbatas hanya dalam bidang penerjemahan. Mereka juga memberikan ta'liq (komentar) atas kitab-kitab tersebut. Mereka menafsirkan teori atau pendapat dalam kitab itu, menukilnya, menyempurnakan kekurangan dan mengoreksi setiap kesalahannya. Aktivitas ini di masa sekarang dikenal dengan tahqiq

\footnotetext{
${ }^{13} \mathrm{Ibn}$ Nadim, Al-Fihrist, hlm. 304.

${ }^{14}$ Ibn Nadim, Al-Fihrist, hlm. 43.
}

$(\text { penelitian })^{15}$.

Qadhi al-Shaid al-Andalusi dalam bukunya Thabaqat al-Umam tentang perkembangan terjemahan dalam Bayt al Hikmah,menyebutkan:

Khalifah al-Ma'mun begitu memerhatikan perpustakaan yang menakjubkan ini. Ketika khalifah Abbasiyah berpindah ke khalifah ketujuh yakni Abdullah bin al-Ma'mun bin Harun al-Rasyid maka diteruskanlah apa yang telah dirintis oleh kakeknya, al-Manshur. Ia menempatkan para penuntut ilmu pada tempatnya, mengeluarkannya dari tambang permatanya, dengan kelebihan cita-citanya yang mulia, kekuatan jiwanya yang utama. Sehingga, mereka mewarnai kerajaan Romawi, memenuhinya dengan hidayah yang sangat penting, menanyakan kepada mereka tentang hubungannya dengan kitab-kitab filsafat pada mereka. Lantas mereka mengutus kepadanya dengan memberikan kitab-kitab Plato, Aristoteles, Abqirath, Jalinus, Euclides, Bathlemus dan sebagaiya dari kalangan filsafat. Kemudian dengan segala kesungguhan mengadakan misi terjemah, memberi mereka upah terjemahnya. Lalu orangorang dianjurkan untuk membacanya, dianjurkan pula untuk mempelajarinya. Maka digemarilah bursa keilmuan pada zamannya. Kemudian berdirilah negara yang penuh hikmah pada masanya, dan menjadi pesona yang menjulang tinggi dalam masalah ilmu dimana mereka memandang dari kecemerlangannya, kekhususan-kekhususan yang menjadi panutan, menjadi satu-satunya cita-cita, merasa senang dengan teori-teori, dan merasa nikmat dengan pembahasan, hingga mencapai derajat yang tinggi, dan posisi yang gemilang ${ }^{16}$.

\footnotetext{
${ }^{15}$ Ibn Nadim, Al-Fihrist, hlm. 339.

${ }^{16}$ Said al-Andalusi, Thabaqat al-Umam, hlm.
} 
Apa yang diceritakan Qadhi Shaid al-Andalusi, menunjukkan fakta bahwa Khalifah al-Ma'mun membentuk tim akademi khusus untuk menerjemahkan bermacam-macam ilmu. Ia merekrut para penerjemah besar dari segala penjuru dunia. Di antaranya adalah Abu Yahya bin al-Bitrik yang termasuk ilmuan berkebangsaan Yunani. Begitu pula Hunain bis Ishak.

Sampai al-Ma'mun wafat, kitab-kitab Yunani, Persia, dan sebagainyaterangkat ke permukaan. Kitab-kitab klasik di bidang matematika, falak (astronomi), kedokteran, kimia, dan arsitektur, ditemukan dalam bahasa Arab diperpustakaan Bayt al-Hikmah. Dikatakan oleh Will Durant pengarang buku The Story of Civilization, kaum Muslimin telah mewariskan dari Yunani sesuatu yang hebat apa yang diwarisinya dari imu-ilmu zaman kuno. Kemudian India menempati kedudukan kedua sesudah Yunani ${ }^{17}$.

3) Pusat Kajian dan Naskah

Ini merupakan hal paling penting bagi perkembangan perpustakaan. Para penulis mengarang kitab-kitab khusus di perpustakaan ini. Para penulis berada di bawah koordinasi divisi penulisan dan penelitian dalam institusi perpustakaan ini. Ada juga yang menulis dan meneliti di luar perpustakaan kemudian karyanya diberikan kepada pihak perpustakaan. Setelah itu para pengarang mendapatkan bayaran yang besar dari khalifah. Para penyalin atau penerjemah di Bayt alHikmah bisa memilih bidang ilmu yang diminatinya. Al-Syu'ubi termasuk ulama abad ketiga yang menyalin dan menerjemahkan kitab di Bayt alHikmah untuk khalifah Ar-Rasyid dan 49.

${ }^{17}$ Will Durant, The Story of Civilization,(London:Mac Milan, 1976),hlm. 40.
Al-Ma'mun.

4) Menara Astronomi (Observatorium Astronomi)

Khalifah al-Ma'mun membangun menara astronomi ini di sebuah tempat bernama al-Syamsyiah, dekat Baghdad, agar bisa memantau posisi Bayt al-Hikmah. Ia mendirikan menara tersebut sebagai laboratorium untuk praktik agar para penuntut ilmu bisa mempraktikan teori-teori ilmiah yang dipelajarinya secara langsung. Menara astronomi ini juga digunakan oleh para ilmuan astronomi, geografi, dan matematika seperti al-Khawarizmi, anak-anak Musa bin Syakir, juga al-Biruni. AlMa'mun termasuk yang sering ikut menggunakan menara tersebut untuk menghitung peredaran bumi.

\section{5) Sekolah}

Khalifah sesudah al-Rasyid pun begitu dekat dengan para ilmuan terkemuka di masa itu. Ia mempercayakan pendidikan keluarga istana kepada para ilmuwan tersebut. Khalifah pun menghadiahkan pemberian yang sangat besar kepada mereka. Di antara para ilmuan itu adalah al-Kisai Ali bin Hamzah ${ }^{18}$, yang begitu diperhatikan dan dicukupi kebutuhannya pada masa al-Ma'mun. Ia adalah guru yang mengajarkan ilmu nahwu pada anaknya. Dia sendiri seorang pengarang ilmu nahwu dan bahasa yang sangat hebat. Selain itu, ada Ibnu Sikit ${ }^{19}$ yang dipercaya mendidik anaknya, Ja'far al-Mutawakil. Sedemikian tinggi

\footnotetext{
${ }^{18}$ Al-Kisai adalah nama dari Abu Hasan Ali bin Hamzah bin Abdullah al-Kufi, ahli dalam ilmu nahwu dan bahasa, salah satu ahli qiroat sab'ah yang terkenal, guru khalifah al-Amin putra Harun al-Rasyid. Ia lahir di Kufah dan wafat di Rayy tahun $805 \mathrm{M}$.

${ }^{19}$ Ibn Sikit adalah nama dari Abu Yusuf bin Yakub bin Ishak, tokoh terkemuka dalam bahasa dan sastra
} 
apesiasi khalifah terhadap para ilmuan sehingga nama-nama mereka diorbitkan sejajar dengan para fuqaha. Gaji mereka pun diperhatikan.Al-Zajaj, misalnya, ia mendapatkan rezeki sebagai fuqaha juga sebagai ulama, dan gajinya itu dua ratus dinar setiap bulan. Sementara ulama lain seperti Hakim al-Muqtadir Ali bin Dar$\mathrm{id}^{20}$ mendapatkan lima puluh dinar pada setiap bulan. Semula, ia datang ke Baghdad dalam keadaan miskin.

Ketika sekolah-sekolah berdiri, lalu ditentukan guru-guru yang mengajar, maka ditetapkanlah untuk mereka gaji bulanan yang diatur oleh bendahara umum. Atau, dari badan-badan wakaf, yang digunakan untuk memberikan infaq untuk urusan tersebut. Gaji ini berbeda-beda menurut kedudukan pengajar dan masukan wakaf, tapi secara umumlebih cenderung mewah dan cukup banyak.

Pada masa al-Rasyid dan alMa'mun, Bayt al-Hikmah begitu besar perannya sebagai sebuah lembaga akademis, tempat bagi pelajar dan pengajar menekuni dunia keilmuan secara intensif $^{21}$. Sedangkan metode yang digunakan dalam pendidikan di Bayt al-Hikmah terdiri atasmetode muhadharah (ceramah), metode dialog dan wawancara serta debat. Guru yang mengisi ceramah-ceramah perkuliahan berada di ruang yang luas. Dia naik ke tempat yang tinggi, kemudian para pelajar berkumpul. Ia terlebih dahulu mempresentasikan kepada mereka apa yang menjadi uraian dari muhadharah, lalu mereka

\footnotetext{
${ }^{20} \mathrm{Ibn}$ Darid adalah nama dari $\mathrm{Abu}$ Bakar $\mathrm{Mu}-$ hammad bin al-Hasan Darid al-Bashri (838933M). Ia tokoh terkemuka di masanya dalam bidang bahasa dan sastra. Lahir di Bashrah dan wafat di Baghdad. Di Antara kitabnya yang terkenal adalah Jamharah al-Lughah.

${ }^{21}$ Will Durant, The Story of Civilization, hlm. 319.
}

berdialog interaktif. Ustadz atau syaikh menjadi rujukan akhir dari materinya. Murid-murid berpindah dari halaqah satu ke halaqah lain, mempelajari berbagai cabang ilmu yang diminatinya ${ }^{22}$.

Pendidikan meliputi cabangcabang ilmu seperti filsafat, falak, kedokteran, matematika, berbagai macam bahasa seperti Yunani, Persia, India, disamping bahasa Arab. Setelah lulus dari proses pendidikan di Bayt al-Hikmah, mereka diberikan ijazah oleh para guru, sebagai bukti bahwa mereka telah mendalami ilmu tersebut. Jika di antara mereka ada yang mendapatkan peringkat istimewa akan diberi ijazah dengan predikat terbaik atau istimewa dalam pelajarannya, dan yang bertindak sebagai orang yang memberikan ijazah itu adalah gurunya bukan orang lain. Di antara cara pemberian ijazah itu adalah sang guru menulis langsung nama murid yang telah lulus, berikut predikatnya, nama syaikhnya, madzhab fikihnya, serta tanggal dikeluarkannya ijazah ${ }^{23}$.

6) Kantor Bayt al-Hikmah

Kantor Bayt al-Hikmah Baghdad dikelola oleh sejumlah mudir (direktur) para ilmuwan. Mereka mendapatkan gelar shahib. Direktur Bayt al-Hikmah ini disebut dengan shahib Baitul Hikmah. Sedangkan mudir pertama Bayt al-Hikmah adalah Sahal bin Harun al-Farisi (215/830 M). Dia diangkat oleh Harun al-Rasyid sebagai penanggung jawab perbendaharaan kitab-kitab Hikmah yang disalin dari bahasa Persia ke bahasa Arab dan apa yang didapatinya dari semua hikmah Persia. Ketika alMa'mun mnenjadi khalifah, dia tetapkan sebagai direktur Bayt al-Hikmah. Dia dibantu orang lain untuk mengelolanya

22Khadhar Ahmad Athaillah, Bayt al-Hikmah $\mathrm{fi}$ 'Ashr Abbasiyyin, hlm. 246.

${ }^{23}$ Will Durant, The Story of Civilization, hlm. 36. 
yakni Said bin Harun yang dijuluki dengan Ibn Harim. Ada lagi yang diangkat di kantor Bayt al-Hikmah yakni Hasan bin Marar al-Dzahabi.

Dalam hal ini, al-Qalqasyandi memberikan gambaran tentang perpustakaan Baghdad dengan ungkapan, "Koleksi buku yang paling besar dalam Islam ada tiga. Salah satunya adalah koleksi Khalifah Abbasiyah di Baghdad. Di sana terdapat buku-buku yang tidak diketahui berapa banyaknya, dan tidak ada yang dapat menyamai kemegahannya; sedang koleksi besar yang kedua adalah di Kairo, kemudian ketiga di Cordova."

Semua itu menunjukkan betapa banyak perpustakaan yang tidak kecil perannya dari perpustakaan Baghdad di dunia Islam. Demikian itu dikarenakan para khalifah dan penguasa kaum Muslimin, berlomba-lomba mengumpulkan buku, sampai-sampai al-Hakam bin Abdurahman al-Nashir, salah seorang khalifah Andalusia, mengutus orangorang ke seluruh penjuru negeri timur, untuk membelikannya kitab-kitab, pada awal masa kekuasaanya.

Perpustakaan Baghdad dan perpustakaan-perpustakaan Islam lainnya berperan besar dalam kebangkitan ilmu di segala ruang lingkup kehidupan kaum Muslimin pada abad 8-10 M. Di saat kaum Muslim sedang berjaya dengan segala aktivitas keintelektualan, bangsa Eropa masih terlelap tidur dalam keterbelakangan dan perselisihan mereka dengan suku-suku di antara mereka.

Perpustakaan juga digunakan untuk mencetak banyak ilmuwan yang menjadi penggerak berbagai disiplin ilmu pengetahuan. Di antara para ilmuwan tersebut adalah al-Khawarizmi, seorang pencipta ilmu aljabar. Dalam hal ini, Ibn Nadim menceritakan peran al-Khawarizmi yang sangat luar biasa dalam bidang ilmu falak. Dia berkata, "Di perpustakaan Bayt al-Hikmah, alKawarizmi adalah pakar dalam bidang astronomi dan ilmu tata surya, dimana orang-orang sebelumnya mempercayakan ilmu-ilmu dan praktek astronomi kepada dokumen-dokumen India."

Begitu pula al-Razi, Ibnu Sina, al-Biruni, al-Battani ${ }^{24}$, Ibnu Nafis, al-Idrisi ${ }^{25}$, dan ratusan ilmuan lain yang turut berkiprah dalam pemikiran Islam, yang menggali penemuan-penemuannya di perpustakaan Baghdad dan perpustakaan Islam lainnya.

Diperkirakan, orang-orang Tartar telah membawa kitab-kitab bernilai ini ke ibukota Mongol untuk dimanfaatkan, padahal mereka waktu itu masih terbelakang dalam hal peradaban. Namun orang-orang Tartar sendiri dikenal suka menghancurkan, tidak suka membaca dan tidak tertarik untuk belajar. Hidup mereka hanya untuk memuaskan nafsu syahwat dan kenikmatan semata. Orang-orang Tartar melemparkan peninggalan Islam ke sungai Tigris sehingga warna air sungai itu berubah menjadi hitam karena tinta buku. Bahkan, ada yang mengatakan tentara berkuda pasukan Tartar menyeberangi sungai di atas jilid-jilid buku yang besar dari tepi sungai ke tepi yang lain. Ini puncak kejahatan yang melanggar hak kemanusiaan ${ }^{26}$.

Yang sangat disayangkan, se-

\footnotetext{
${ }^{24} \mathrm{Al}$-Batani adalah nama dari Abu Abdullah Muhammad bin Jabar bin Sinaan al-Kharani, seorang ahli falak dan arsitek.

${ }^{25} \mathrm{Al}-$ Idrisi adalah nama dari Abu Abdullah $\mathrm{Mu}-$ hammadbin Abdullah bin Idris, seorang ahli geografi yang hidup tahun 1100-1165.

${ }^{26}$ Raghib al-Sarjani, Qishah Tartar min al-Bidayah ila 'Ain Jalut, (Kairo: Maktabah al-Nahdah al-Mishriyah, 1973), hlm. 161-162.
} 
dikit dari karangan ilmiah yang dapat diselamatkan dari kehancuran di tangan orang-orang yang gemar berperang tersebut. Bila ada karya yang berhasil diselamatkan tidak sedikit di antaranya diakui banyak kalangan ilmuan Barat sebagai temuan mereka.Karena itu, perpustakaan Bayt al-Hikmah, Baghdad, sangat berperan besar dalam peradaban keilmuan dan kemanusiaan yang mengilhami temuan-temuan keilmuan pada masa sekarang.

\section{Toko Buku}

Kecuali perpustakaan, tempat yang tidak kalah penting bagi transmisi ilmu pengetahuan muslim adalah toko buku. Pada zaman Abbasiyah tokotoko buku berkembang pesat di wilayah Timur Tengah dan peran pentingnya menyebar di seluruh wilayah Islam, khususnya melalui Afrika Utara dan semenanjung Iberia.

Sebelum penghancuran oleh pasukan Mongol, Bagdad memiliki 100 penjual buku. Selain itu kota Shiraz, Mosul, Basrah, Kairo, Cordova, Fez dan Tunis juga memiliki banyak penjual buku. Para penjual dan pembeli manuskrip memberikan andil yang besar bagi kehidupan intelektual dalam sebuah masyarakat melalui karya-karya pilihan mereka yang diterjemahkan dari bahasa Yunani, Parsi atau bahasa-bahasa timur dan melalui karya-karya berbahasa Arab yang disalin dan disediakan untuk umum.

Toko-toko buku berfungsi sebagai rumah lelang bagi pandanganpandagan Islam menjelang abad ke13. Para saudagar bukuntidak hanya membeli dan menjual buku-buku untuk para langganannya, mereka juga memberikan pelayanan bagi industri perbukuan. Dalam hal ini mereka seringkali berfungsi seperti sebuah percetakan di perguruan tinggi yang muncul belakangan di Eropa dan Amerika. Pengenalan kertas dari daerah Samarkand pada abad ke delapan sangat membantu penyebaran karya-karya yang disediakan untuk umum. Di samping kemudahan penggunaan, sampul kulit buatan tangan yang membalut manuskrip sangat merangsang penerbitan itu, di samping sebagai tambahan atas koleksi seorang patron.

Karena toko-toko buku menjadi pusat pengumpulan dan penyebaran buku-buku, tidaklah aneh lingkaranlingkaran studi berkembang dan mengaitkan dirinya dalam bentuk bangunan khusus. Pemilik toko buku biasa berfungsi sebagai tuan rumah dan kadang-kadang sebagai pemimpin lingkaran studi tersebut. Ia dapat mengundang orang-orang pandai dari masyarakat untuk duduk dan mengarahkan diskusi tentang masalahmasalah intelektual dan keagamaan. Para ilmuwan sering datang ke toko tertentu dan bergabung dengan sanggar sastra yang ada di sana dan dibiayai oleh seorang saudagar buku. Walaupun hal ini pasti membuat pedagang buku menjadi kaya melalui penjualan bukubuku yang didiskusikan secara terbuka di Antara para sarjana, tapi proses ini juga memiliki tujuan yang berguna dalam menyebarkan ilmu pengetahuan dan menyediakan karya tulis bagi masyarakat umum. Dengan demikian toko-toko buku dan para pemiliknya telah memberikan sumbangan yang sangat besar bagi kebangkitan intelektual Islam.

\section{Sekilas tentang Al-Fihrist}

Bilakita membahas perpustakaan Islam, secara khusus harus diungkap mengenai kitab al-Fihrits karya Ibn al- 
Nadim. Berdasar sudut pandang sejarah, kitab al-Fihrits merupakan salah satu dokumen terpenting dalam kebudayaan Islam. Banyak sekali pengetahuan kita tentang ilmu-ilmu Islam, baik dalam terjemahan karya-karya klasik berbahasa Arab maupun dalam bentuk buku-buku kreatif hingga dasawarsa terakhir abad kesembilan belas adalah berdasarkan pada informasi yang diperoleh dari indeks tersebut.

Uraian dalam al-Fihrits hampir sama dengan resensi singkat tentang buku-buku yang dimuat dalam kitab itu. Dalam kata pengantar al-Fihrits disebutkan bahwa kitab ini memuat daftar buku-buku dari semua bangsa Arab dan non Arab dari semua cabang ilmu pengetahuan, disertai penjelasan tetang penyusunnya dan kelas-kelas pengarangnya dan silsilah, tanggal lahir, umur tanggal kematian, letak negara serta kelebihan dan kekurangan mereka, sejak masing-masing ilmu pengetahuan tersebut diketemukan untuk pertama kalinya.

Ibn Nadim sendiri memberi penjelasan dalam pendahuluan kitab alFihrist tersebut:

Ini adalah daftar bukubuku dari bangsa Arab dan nonarab yang sedikit banyak ada bahasa Arab dan catatan orang Arabnya, mengenai sebuah bidang ilmu; yang digabungkan dengan catatan tentang para penghimpun dan kategori pengarang dan keturunan mereka, tanggal meninggal mereka, tempat Negara mereka dan jiwa mereka, dari masa ketika masing-masing ilmu pengetahuan untuk pertama sekali diketemukan sampai masa sekarang ini, yaitu tahun $377 \mathrm{H}^{27}$.

Menurut Charles Michael Stanton, kitab al-Fihrist merupakan karya bibliografi yang paling komplit tentang manuskrip-manuskrip yang ditulis atau diterjemahkan oleh sarjana-sarjana Muslim sampai abad kesepuluh $^{28}$.

Indeks itu meliputi tematema perhatian mereka yang bersifat teologis, keagamaan, filologis, gramatikal, moral, dan filosofis. Secara tragis, kitab al-Fihrist sekaligus mengungkapkan betapa besarnya kehilangan dunia,dengan menunjukkan sumbangan yang tak ternilai harganya bagi dunia ilmu pengetahuan tapi sudah tak lagi tersedia.Hanya beberapa judul saja dari daftar Ibn Nadim yang masih dikenal sekarang ini. Kandungankandungan dari karya-karya selebihnya sudah lama hilang dari dunia intelektual ${ }^{29}$.

\section{Riwayat Kehancuran Perpus- takaan Islam}

Amat disayangkan bahwa perpustakaan-perpustakaan yang menjadi pusat warisan intelektual Islam yag demikian kaya harus mengalami nasib yang menyedihkan. Banyak di antaranya yang hancur. Kehancuran perpustakaan Islam di berbagai tempat disebabkan oleh faktor yang berbedabeda. Perpustakaan Muslim di Tripoli telah dihancukan oleh tentara Perang Salib, atas komando seorang rahib yang tak senang saat menemukan banyak

${ }^{27}$ Charles Michael Stanton, Higher Learning in Islam, (Rowman Publisher, 1990), hlm. 164.

${ }^{28}$ Michael Stanton, Higher Learning in Islam, hlm. 164.

${ }^{29}$ Michael Stanton, Higher Learning in Islam, hlm. 165 . 
Quran di sana.Perpustakaan Sultan Ibn Mansur telah seluruhnya terbakar segera setelah Ibn Sina berhasil menyelesaikan penelitiannya di sana.

Ketika kelompok bangsa Mongol dan Tartar menjarah Bagdad, mereka membakar semua perpustakaan. Bangsa ini mempunyai watak perampok, pembunuh sekaligus pemusnah. Mereka membunuh siapapun yang ditemuinya di Baghdad. Demikian juga mereka akan menghancurkan bangunan yang ada di depan mereka seindah dan sekokoh apapun bangunan itu. Ibn Khaldun pernah menyatakan bahwa sebelum mereka menyerbu Bagdad, jumlah penduduk di sana sebanyak 2 juta orang. Setelah terjadi pembantaian jumlah penduduk yang tersisa hanya 400.000 orang. Berarti telah terjadi pembantaian sebanyak $\quad 1.600 .000 \quad$ orang $^{16}$. Mengomentari penghancuran Bagdad oleh tentara Mongol Dr. Nurchloish Majid dalam suatu perkuliahan di Pascasarjana IAIN Jakarta, 1996, pernah menyatakan bahwa "tragedi itu bukan hanya paling besar dalam sejarah Islam tetapi merupakan terbesar dalam sejarah peradaban umat manusia". Penghancuran oleh bangsa Mongol ini juga dilakukan terhadap perpustakaan di Samarkand dan Bukhara sampai Baghdad.

Dari perpustakaan al-Hakim di Kairo Tahun 1068, perdana menteri Abul Faraj membawa buku-buku sebanyak 25 ekor unta beban dan menjualnya 1.000 .000 dinar untuk membayar tentaranya. Beberapa bulan kemudian buku-buku tersebut jatuh ke tangan tentara Turki setelah menaklukkan Khalifah dan menjarah istananya. Mereka merobek sampul buku yang terbuat dari kulit yang indah itu kemudian dijadikannya sepatu.
Manuskrip-manuskripnya ditimbun dalam sebuah tumpukan lalu dibakar.

Perpustakan Ben Fatiq isinya telah dilemparkan oleh istrinya ke kolam air di halaman rumahnya yang luas. Pasalnya ia dendam dan cemburu pada almarhum suaminya yang mencintai buku-buku daripada dirinya.

Di Spanyol semua perpustakaan
pribadi dan umum mengalami kemusnahan ketika bangsa Moor diusir oleh Raja Kristen tahun 1492. Ribuan buku berbahasa Aran dibakar. Tiga pilihan keputusan yang dapat diambil oleh orang Arab Muslim waktu itu: dibunuh, masuk Kristen, atau hengkang dari Spanyol. Hal itu dapat disebabkan karena dendam sejarah yang berlarutlarut akibat posisi mereka selama hampir 8 abad berada di bawah kekuasaan Islam. ${ }^{30}$

Menurut Stanton, penghancuran perpustakaan yang luas, yang menyimpan koleksi-koleksi keislaman terjadi dalam rentang waktu yang panjang dan tidak dapat dijelaskan oleh hanya satu alasan. Banyak tokoh dan peristiwa terlibat untuk memiskinkan dunia dari warisan yang luar bisa ini. Yang pasti, koleksi-koleksi pribadi telah menjadi barang antic bagi keluarga yang beruntung. Tidak setiap putra dari seorang ayah menghargai manuskripmanuskrip yang telah diusahakan keluarganya dengan harga mahal selama beberapa generasi. Namun demikian, hilangnya karya keislaman yang terdiri dari banyak seri jelas dapat dikaitkan dengan peristiwa-peristiwa politik dan social. Selama penaklukan-penaklukan mereka di Timur Tengah pada abad ke13, pasukan Mongol tidak menunjukkan kecintaannya pada dunia pendidikan

\footnotetext{
${ }^{30}$ Michael Stanton, Higher Learning in Islam, hlm. 170 .
} 
dan tidak menghargai kekayaan. Mereka menghancurkan keseluruhan kota dan menyebabkan koleksi perpustakaan hilang dalam pembakaran-pembakaran.

Jumlah seri yang dihancurkan karena sentimen keagamaan tentara Salib bahkan tidak diperkirakan. Perpustakaan besar di pusat-pusat kebudayaan Moor juga punah karena kebringasan orangorang Kristen yang menghancurkan apa yang mereka anggap sebagai bukubuku berbahaya yang menyelewengkan ajaran heretic dan mengandung ilmu mistik orang-orang kafir. Sedikit koleksi di Cordova, Granada, dan Toledo masih tersisa. Untungnya, banyak karya terbaik pemikiran keislaman sudah diterjemahkan ke dalam bahasa Latin sebelum peristiwa penghancuran ini ${ }^{31}$.

Tingkat kerusakan terhadap ilmu pengetahuan dan pendidikan di perpustakaan-perpustakaan utama Islam oleh bangsa Mongol, tentara Salib, orang-orang Kristen Barat, Turki, Jamaah yang fanatik terhadap suatu aliran, atau karena kebakaran, betul-betul menjadi musibah bagi dunia Intelektual Islam. Tampaknya, bila hal itu tidak terjadi, dunia Islam tidak mengalami hal seperti sekarang. Untungnya banyak karyakarya asli para ilmuwan terbesar seperti Ibn Sina, Ibn Rusyid, Ibn Khaldun, al-Razi, Hafiz, Sa'di, dan Firdawsi dapat diselamatkan dari penghancuran perpustakaan-perpustakaan itu.

The Dark Age of Islam atau abad kegelapan Islam di abad pertengahan Masehi boleh jadi diakibatkan oleh putusnya mata rantai antara masa keemasan perpustakaan Islam dengan zaman dan situasi pascapembumihangusan perpustakaan tersebut. Akibat lebih lanjut adalah umat

\footnotetext{
${ }^{31}$ Michael Stanton, Higher Learning in Islam,
} hlm. 171.
Islam tidur lelap selama hampir 1000 tahun.

\section{Penutup}

Dari uraian di atas dapat disimpulkan bahwa perpustakaan di masa kejayaan Islam abad 8-10 M telah menjadi bagian yang tidak terpisahkan dari perjalanan intelektualitas masyarakat Muslim. Kehadiran perpustakaan dapat disimpulkan sebagai salah satu factor utama terjadinya akselerasi peradaban keilmuan Islam. Tanpa kehadiran perpustakaan sulit dipastikan akan terjadinya The Golden Age of Islam di tiga abad tersebut. Kehadiran perpustakaan dan menjamurnya para ilmuwan Muslim adalah simbiose mutualistic yang sungguh mengagumkan. Perpustakaan membutuhkan para ilmuwan sebagai aktor di balik kerja ilmiah akademis, dan para ilmuwan pun membutuhkan perpustakaan sebagai bahan telaah pengembangan keilmuannya.

Perpustkaan dalam sejarah Islam tidaklah tunggal melainkan dapat berfungsi sebagai: tempat mencari bahan referensi bagi para penuntut ilmu di berbagai tingkat pendidikan; bahan kajian para intelektual Islam; pusat penyimpanan buku-buku dan manuskrip berharga karya ilmuwan; sebagai tempat pertemuan untuk kepentingan diskusi ilmiah dan debat intelektual, dan menjadi simbol kebanggaan khalifah dan penguasa setempat.

Perpustakaan paling terkemuka dengan jumlah bahan pustaka terbesar, pengelolaan yang rapi, jumlah pengguna yang banyak, dan pendayagunaan yang multifungsi adalah Bayt alHimah di Bagdad. Perpustakaan ini dirintis oleh Abu Ja'far al-Mansur, khalifah kedua Dinasti Abbasiyah. Di 
masa Harun al-Rasyid dan al-Ma'mun pendayagunaannya makin ditingkatkan secara massif. Kedua khalifah tersebut memang terkenal karena apresiasinya yang demikian besar pada dunia keilmuan sehingga pada masanya supremasi kehidupan dalamaspek keilmuan, peradaban dan kebudayaan memperoleh masa keemasannya.

\section{Daftar Pustaka}

Amin, Ahmad, Dhuha al-Islam, Kairo: Maktabah al-Nahdah al-Mishriyah, 1933.

Audah, Ali, Dari Khazanah Dunia Islam, Jakarta: Pustaka Firdaus, 1999.

Athaillah, Khadhar Ahmad, Bayt al-Hikmah fi 'Ashr Abbasiyyin, tanpa penerbit, t.th.

Bakhs, Salahuddin Khuda and D.S.Margoliouth, , The Renaissance of Islam, New Delhi: Kitab Bhavan, 1995.

Durant, Will, The Story of Civilization, London:Mac Milan, 1976.

Fakhry, Majid, A History of Islamic Philosophy, Columbia University Press, 1983.

Herianto, Husain, Menggali Nalar Saintifik Peradaban Islam, Bandung: Mizan, 2011.

Hitti, Philip K. ,History of The Arabs, London:Mac Milan, 1974.

Faruqi, Isma'il Raji al-, The Cultural Atlas Of Islam, New York : MacMilan, 1982.

Hart, Michael, Seratus Tokoh yang Palin Berpengaruh Dalam Sejarah, Jakarta : Pustaka Jaya, 1983.

Hasan, Said Ahmad, Anwa al-Makta- bat $f i$ al-Alamina wa al-Islam, Kairo: Maktabah al-Nahdah al-Mishriyah, 1933.

Katsir, Ibn, Al-Bidayah wa al-Nihayah, Beirut: Dar el-Fikr, 1933.

Khalikan, Ibn, Wafiat al-A'yan wa anba abna al-Zaman, Kairo: Maktabah al-Nahdah al-Mishriyah, 1937.

Makdisi, George, The Rise Of College, Institution Of Learning In Islam and The West, Edinburgh University Press, 1981.

Mahmudunnashir, Syed, Islam Its Concept and History, Bandung: Remaja Rosdakarya, 1991.

Nakosteen, Mehdi, History Of Islamic Origins Of Western Education A.D. 800-1350; with an Introduction to Medieval Muslim education, Terj. Joko S. Kahar, Surabaya:Risalah Gusti, 1996.

Nadim, Ibn, Al-Fihrist, Kairo: Maktabah al-Nahdah al-Mishriyah, 1935.

Nasr, Sayyed Hossain, Science And Civilization in Islam, Terj. Mahyudin, Bandung :Pustaka, 1986.

Nawawi, al-, Sahih Muslim bi Syahrh Imam Al-Nawawi, Mesir; Al-Maktabah, 1924.

Sharif, M.M., A History of Muslim Philosophy, Wiesbaden: Otto Harroswith, 1963.

Shihab, Quraish, Membumikan Al-QuranBandung : Mizan, 1993.

Sarjani, Raghib al-, Qishah Tartar min al-Bidayah ila 'Ain Jalut, Kairo: Maktabah al-Nahdah al-Mishriyah, 1973. , Sumbangan Peradaban Islam 
pada Dunia, Jakarta: Pustaka alKautsar, 2009.

Stanton, Charles Michael, Higher Learning In Islam, The Classical Period, A.D. 700-1300, Terj. H. Affandi, Jakarta:Logos, 1994.

Shalaby, Ahmad, History Of Muslim Education, Beirut: Dar al-Kashshaf, 1954.

Saefuddin, Didin, Zaman Keemasan Islam, Jakarta: Grasindo, 2002.

Syuhbah, Muhammad Ibn, Fi Rihab Al-Sunnah Al-Kutub Al-Shihhah Al-Sittah, Kairo :Silsilah AlBuhuts, Al-Islamiyah, 1969.

Watt, W. Montgomery, The Influence Of Islam On Medieval Europe, Edinburgh University Press:1972

Ulyan, Raihi Mustafa, Al-Maktabah $f i$ al-Hadharah al-Arabiyah al-Islamiyah. Beirut: Dar alKashshaf, 1964.

Zahabi, Muhammad Hussain al-, Al-Tafsir wa al-Mufassirun, Kairo : Dar Al-Kutub Al-Haditsah 1961. 